\title{
Passiflora edulis: new natural host of Melochia yellow mosaic virus in Brazil
}

\author{
D. M. A. Spadotti ${ }^{1}$ • V. H. Bello ${ }^{2}$ • G. M. Favara ${ }^{1}$ • O. S. Stangarlin ${ }^{3} \cdot$ R. Krause-Sakate ${ }^{2}$ • J. A. M. Rezende ${ }^{1}$
}

Received: 3 April 2019 / Accepted: 8 July 2019 /Published online: 12 July 2019

(C) Australasian Plant Pathology Society Inc. 2019

\begin{abstract}
Begomovirus infections in Passiflora plants in Brazil have increased in recent years. This contribution reports natural infection of Passiflora plants by Melochia yellow mosaic virus (MelYMV) in the state of Mato Grosso do Sul. MelYMV was transmitted to Passiflora plants by biolistics but not by Bemisia tabaci MEAM1 and MED. To our knowledge this is the first report of MelYMV infecting Passiflora plants.
\end{abstract}

Keywords Passifloraceae $\cdot$ Begomovirus $\cdot$ Bemisia tabaci $\cdot$ Diagnosis

Brazil is the world's largest producer of yellow passion fruit (Passiflora edulis). Passiflora plants are affected by the potyvirus Cowpea aphid-borne mosaic virus (CABMV) in all producing regions in the country. Recent years have seen frequent reports of Passiflora plants infected by begomoviruses, transmitted by the whitefly Bemisia tabaci (Novaes et al. 2003; Ferreira et al. 2010; Mituti et al. 2019). In 2016, eight samples of Passiflora plants, variety Sol do Cerrado, exhibiting symptoms of begomovirus infection including mosaic, yellow spots, leaf curling and malformation were collected in an orchard in the state of Mato Grosso do Sul. Total DNA was extracted from each sample according to the protocol described by Doyle and Doyle (1990) and analysed by PCR using the universal pair of degenerate primers PAR1c496/PAL1v1978

J. A. M. Rezende jrezende@usp.br

1 Departamento de Fitopatologia e Nematologia, ESALQ-USP, Piracicaba, SP 13418-900, Brazil

2 Departamento de Proteção Vegetal, FCA-UNESP, Botucatu, SP 18610-307, Brazil

3 AGRAER/CEPAER, Campo Grande, MS 79114-000, Brazil
(Rojas 1993), which amplify part of the ORF AC1 (Rep), the common region and part of the ORF AV1 (CP) of DNA-A of begomoviruses. Two randomly chosen amplicons of $1100 \mathrm{bp}$ were directly sequenced at Macrogen, Seoul, South Korea. Comparison of nucleotide sequences of different begomoviruses available from GenBank revealed 94-95\% identity with the corresponding sequence of Melochia yellow mosaic virus (MelYMV) (GenBank accession no. KT201153), previously reported to infect plants of Melochia sp. (FialloOlivé et al. 2015). To obtain the complete nucleotide sequence of the DNA-A, three pairs of primers were synthesised based on the nucleotide sequence of MelYMV (749F- 5'-CCGTGATCGTTTCAAGTCA-3' and 2123R - 5'-GCAATAAACGCCTCCTCAAA-3'; 247F - 5'-ATAATGCCTAAGCGGGAAGC-3' and 630R - 5'-AGGCACTAAACGCCTTCTCA-3'; 889F - 5'GGRTTHGARGCATGSGTACATG-3' and 325R - 5'GCCYATRTAYAGRAAGCCMAG-3'). The amplicons obtained by PCR were directly sequenced and the DNA-A sequence was assembled with Geneious 8.1.9 (Biomatters Ltd.). The DNA-A is $2595 \mathrm{nt}$ long (GenBank accession no. MG461177) and showed 95\% identity with MelYMV DNA-A (KT201153). The DNAA amplicon obtained from total DNA of field-infected Passiflora leaves by rolling-circle amplification (RCA) was inoculated using the PDS1000/He biolistics system 

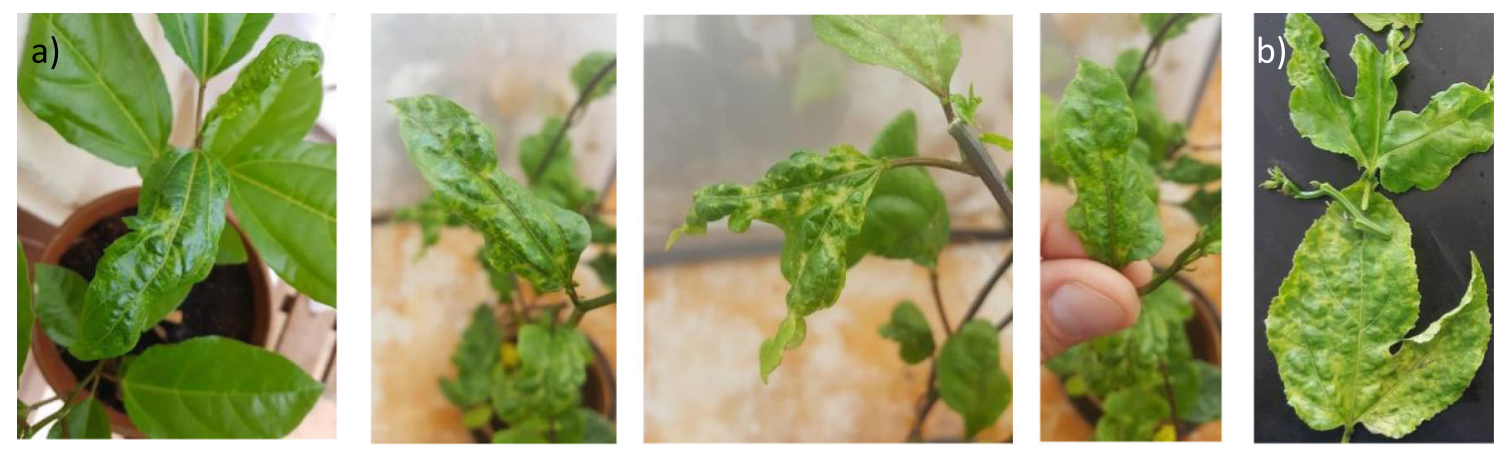

Fig. 1 Symptoms of Melochia yellow mosaic virus in leaves of Passiflora edulis Sims. a plant of variety FB-200 inoculated by biolistics. b field-infected plant of variety Sol do Cerrado

(Bio30 Rad) into nine Passiflora plants of variety FB200 and five plants of Sida rhombifolia. After 30 days, three Passiflora plants developed symptoms similar to those exhibited by field-infected plants (Fig. 1), and MelYMV infection was confirmed by PCR. Plants of $S$. rhombifolia were not infected. Transmission assays were performed with the whiteflies B. tabaci MEAM1 and MED, to Passiflora, cotton, tomato, pepper and $S$. rhombifolia plants, using experimentally infected Passiflora leaves as sources of inoculum. None of the inoculated test-plants exhibited symptoms of viral infection, nor was MelYMV detected by PCR 30 days after inoculation. Absence of experimental transmission of a different begomovirus by B. tabaci MEAM1 was previously reported by Novaes et al. (2003). To the best of our knowledge, this is the first report of natural infection of Passiflora plants by MelYMV. Studies are needed to evaluate the incidence of this begomovirus in Passiflora orchards in Mato Grosso do Sul and the potential to reduce the production of passion fruit.

Acknowledgements This study was supported by the Fundação de Amparo à Pesquisa no Estado de São Paulo (FAPESP), Project No. 2016/08573-8.

\section{References}

Doyle JJ, Doyle JL (1990) Isolation of plant DNA from fresh tissue. Focus 12:13-15

Ferreira SS, Barros DR, Almeida MR, Zerbini FM (2010) Characterization of Passionfruit severe leaf distortion virus, a novel begomovirus infecting passionfruit in Brazil, reveals a close relationship with tomato-infecting begomoviruses. Plant Pathol 59:221230. https://doi.org/10.1111/j.1365-3059.2009.02205.x

Fiallo-Olivé E, Zerbini FM, Navas-Castillo J (2015) Complete nucleotide sequences of two new begomoviruses infecting the wild malvaceous plant Melochia sp. in Brazil. Arch Virol 160:3161-3164. https://doi. org/10.1007/s00705-015-2619-4

Mituti T, Spadotti DMA, Narita N, Rezende JAM (2019) First report of Sida mottle Alagoas virus infecting Passiflora edulis in Brazil. Plant Dis 103:169. https://doi.org/10.1094/PDIS-06-18-1068-PDN

Novaes QS, Freitas-Astua J, Yuki VA, Kitajima EW, Camargo LEA, Rezende JAM (2003) Partial characterization of a bipartite begomovirus infecting yellow passionflower in Brazil. Plant Pathol 52:648-654. https://doi.org/10.1046/j.1365-3059.2003. 00878.x

Rojas MR (1993) Use of degenerate primers in the polymerase chain reaction to detect whitefly-transmitted geminiviruses. Plant Dis 77 : 340. https://doi.org/10.1094/PD-77-0340 